\title{
WORKSHOP PENINGKATAN KUALITAS SDM BAGI CALON GURU FISIKA MELALUI MEDIA PRAKTIKUM KOMPONEN ELEKTRONIKA PASIF DAN AKTIF
}

\author{
Kurriawan Budi Pranata ${ }^{1}$, Chandra Sundaygara², Muhammad Sayadi ${ }^{3}$, Sholikan $^{4}$, Hari \\ Wijaya $^{5}$, Muhammad Ghufron ${ }^{6}$ \\ 1,2,3,4 Fakultas Sains dan Teknologi, Program Studi Pendidikan Fisika, Universitas Kanjuruhan \\ Malang \\ ${ }^{5}$ Fakultas Ilmu Pendidikan, Program Studi Pendidikan Pancasila dan Kewarganegaraan, \\ Universitas Kanjuruhan Malang \\ ${ }^{6}$ Fakultas Matematika dan Ilmu Pengetahuan Alam, Jurusan Fisika, Universitas Brawijaya \\ Malang \\ Email:kurriawan@unikama.ac.id
}

\begin{abstract}
Prospective physics teachers are the seeds of the next generation to spread science. But the understanding of science has been balanced with standard laboratory facilitation. In fact there are still many public and private schools that do not have adequate laboratory facilities. Whereas a physics teacher candidate must be able to teach in all fields and conditions. This is a challenge for prospective physics teachers. So the importance of conducting workshops to conduct a learning approach using methods of using practicum media by optimizing the surrounding environment such as the use of passive and active electrical component materials. The implementation of this activity is carried out for six hours consisting of 1. Introduction 2. Characterization 3. Implementation. The results of this dedication activity the prospective physics teachers are very enthusiastic because so far the physics candidates are only limited to knowing but do not understand the physical or physical meaning.
\end{abstract}

Keywords: workshops, passive and active electrical component materials.

\begin{abstract}
Abstrak:Calon guru fisika merupakan bibit generasi penerus penyebaran ilmu sains. Namun pemahaman ilmu sains telah diimbangi dengan fasilitasi laboratorium yang standart. Pada kenyataannya masih banyak sekolah negeri maupun swasta tidak memliki fasilitas laboratorium yang memadai. Sedangkan seorang calon guru fisika harus mampu mengajar disegala medan dan kondisi. Hal inilah menjadi tantangan tersendiri bagi seorang calon guru fisika. Sehingga pentingnya dilakukan workshop untuk melakukan pendekatan pembelajaran menggunakan metode penggunaan media praktikum dengan mengoptimalkan lingkungan sekitar seperti penggunaan bahan-bahan komponen listrik pasif dan aktif. Pelaksanaan kegiatan ini dilakukan selama enam jam yang terdiri dari 1. Pengenalan 2. Pengkarakterisasian 3. Penerapan. Hasil dari kegiatan penabdian ini para calon guru fisika sangat antusias karena selama ini para calon fisika hanya sebatas tahu tapi tidak memahami secara fisik maupun makna fisis.
\end{abstract}

Kata Kunci: Workshop; Komponen Pasif; Komponen Aktif. 


\section{PENDAHULUAN}

Pendidikan pada dasarnya bertujuanmengembangkanwatak dan potensi peserta didik agar menjadi manusia yang berketuhanan dan memiliki budi pekerti yang luhur, berilmu, kreatif, mandiri, dan serta bertanggung jawab. Oleh karena itu, rumusan tujuan pendidikan nasional dihadikan sebagai konsep dasar dalam pengembangan pendidikan karakter bangsa (Gaffar. A. A, 2019) termasuk dalam mata pelajaran fisika.

Mata pelajaran fisika di sekolah menengah pada umumnya memberikan bekal pengetahuan, serta meningkatkan kreativitas dan sikap ilmiah. Pembelajran fisika hendaknya peserta didik difasilitasi dan diberikan kesempatan untuk berkreasi pada saat proses pembelajaran melalui suatu kegiatan praktikum yang membutuhkan obyek, benda nyata, atau alat peraga yang seringkali kita sebut sebagai media sebagai pemicu interaksi ilmiah antar teman sebaya dan guru.Kegiatan tersebut dilakukan berdasarkan pengamatan, merumuskan masalah, merencanakan penyelidikan, melakukan percobaan, menggunakan perangkat untuk mengumpulkan data, menganalisis data, menemukan jawaban, dan melakukan prediksi serta mengkomunikasikan hasil yang diperoleh (Sukartini dan Faisal, 2009).

Interaksi komunikasi tersebut harus dibangun berdasarkan pengalaman empiris, dimana konsep-konsep diformulasikan berdasarkan fakta dan data hasil pengamatan terhadap gejala, baik gejala alamiah maupun yang dikondisikan.Meskipun sebagian dari konsep fisika dibentuk melalui analisis matematis, namun pada akhirnya teori yang dibentuk harus diuji melalui eksperimen.Kegiatan experimen di laboratorium lebih efektif untuk memperoleh kemampuan pengamatan dan keterampilan teknik, serta melalui kegiatan ini peserta didik mampu mencapai tiga ranah secara bersamasama, yaitu; (1) Tingkat kognitif dimana dapat memahami teori dan menerapkan teori pada permasalahan nyata; (2) Afektif yaitu merencanakan kegiatan secara mandiri, bekerja sama, dan mengkomunikasikan informasi; dan (3) Psikomotor dengan belajar memasang peralatan sehingga betul-betul berjalan, memakai peralatan dan instrumen tertentu (Erniwati dkk, 2014).

Ketiga ranah berupa kognitif, afektif, psikomotorik tersebut dapat dilakukan secara bersama pada saat proses pembelajaran melalui ketersediaan suatu alat peraga atau yang kita sebut media pembelajaran. Media pembelajaran merupakan hal yang harus dipahami dan dikembangkan guna meningkatkan kualitas pembelajaran dan profesionalisme seorang guru. Oleh sebab itu, seorang guru harus mampu memberikan media pembelajaran yang variatif, menarik, mudah dirangkai, murah secara finansial, dan mengoptimalkan kondisi lingkungan sekitar.Guru merupakan tokoh utama dalam penyampaian materi ajar yang memiliki peran andil dalam mengarahkan siswa untuk mencapai capaian pembelajaran. Hal ini tentunya harus ditunjang dengan kondisi lingkungan psikologis yang menyenangkan, mudah dalam penyampaiannya materi, aplikatif, dan edukatif (Chairuddin, 2019). 
Pengkondisian lingkungan psikologis tentunya dilakukan dengan mengaitkan proses pembelajaran melalui kegiatan praktikum. Sehingga media pembelajaran yang disampaiakn kepada peserta didik diharapkan dapat dimaksimalkan guna meningkatkan keberhasilan proses belajar mengajar. Pembelajaran praktikum merupakan solusi secara efektif untuk digunakan sebagai pendorong peserta didik agar belajar secara aktif merekonstruksi pemahaman konseptualnya (Duda, 2010).Rustaman, et al., (2005) mengemukakan bahwa dalam pendidikan sains kegiatan praktikum merupakan bagian integral dari kegiatan belajar mengajar.Hal ini menunjukkan peranan yang penting dari kegiatan praktikum untuk mencapai capaian pembelajaran bidang sains.Selain itu Rustaman, et al., (2005) mengemukakan empat alasan mengenai pentingnya kegiatan praktikum sains, yaitu (1) dapat membangkitkan motivasi belajar siswa; (2) mengembangkan keterampilan dasar melakukan eksperimen; (3) menjadi wahana belajar pendekatan ilmiah; serta (4) menunjang materi pelajaran.

Pada kenyataannya diberbagai sekolah negeri maupun swasta, kegiatan praktikum tidak dapat dimaksimalkan karena alat-alat laboratorium yang dimiliki sekolah sangat terbatas, tidak memadai bahkan tidak memiliki alat-alat laboratorium.Hal ini terjadi karena mahalnya pengadaan barang tentang seperangkat kit lapboratorium yang standart yang mengakibatkan pihak sekolah enggan untuk mengembagkan suasana laboratorium dilingkungan sekolah masing-masing. Selain itu juga, pihak sekolah juga tentunya harus menyediakan pegawai laboran untuk menjaga kelestarian alat-alat laboratorium yang sudah dikembangkan.Selain itu juga, asumsi pihak sekolah juga harus bersedia menyediakan anggaran rutin untuk menyediakan bahan habis pakai, bahan pesediaan, maupun anggaran maintence jika terdapat suatu kerusakan pada suatu alat peraga yang seringkali digunakan oleh peserta ddik.Tentunya hal ini menjadi permasalahan yang serius dalam dunia lingkungan persekolahan.Seringkali peserta didik maupun guru dilingkungan sekolah tersebut minim ketrampilan dalam menggali kemampuan berpikir secara ilmiah dalam materi pokok konsepkonsep sains. Sehingga pembelajaran yang dilakukan dilingkungan persekolahan cenderung hanya sebatas duduk diam menyelesaikan masalah sains hanya sebatas penyelesaian soal yang terdapat pada lembar kerja siswa berupa konsep teoritis dan pemberian persamaan rumus-rumus matematis tanpa tersediaanya peluang kesempatan kepada peserta didik untuk melakukan kegiatan menggali kreatifitas dan ketrampilan poroses sains. Oleh sebab itu kerap kali mata pelajaran sains fisika dianggap sulit, membosankan, kurang menarik dan kurang menyenangkan.Hal ini senada seperti yang diungkapkan pada diagram kerucut pengalaman pembelajaran dan tahapan media pembelajaran seperti yang dtunjukkan pada Gambar 1 yang mengungkapkan pengalaman langsung merupakan menuju pembelajaran secara kongkret dibandingkan dengan penjelasan teori lambing kata maupun lambing visual. 


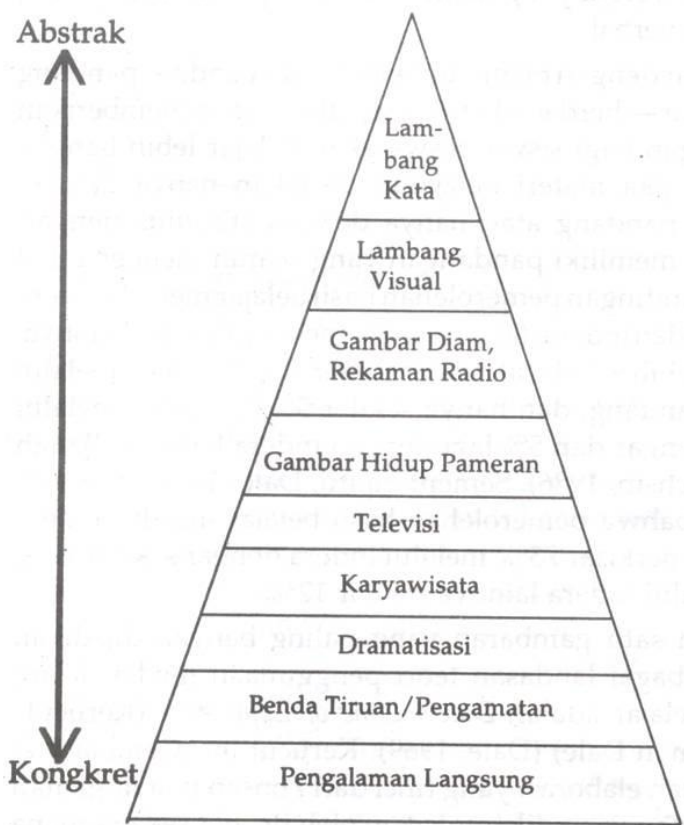

Gambar 1. Kerucut Pengalaman

Dale (alhikmahsby.com).

Telah ditunjukkan pada Gambar 1 bahwa tahapan pengalaman belajar sangat erat dengan memori peserta didik terhadap metode perlakuan yang dilakukan pada saat proses pembelajaran.Pada tahapan lambang kata dan lambag visual merupakan hanya perlakuan verbal yang hanya menyerap memori pengethuan secara 10\%-20\%.Sedangkan tahapan Gambar diam sampai dramatisasi hanya mampu menyerap memori hingga 20\%70\%.Sementara pada tahapan pengamatan samapai pengalaman langsung dapat menyerap memori hingga 70\%-90\%.Artinya segala tahapan ini tentunya dapat dijadikan acuan pemberian treatment pada profesionalisme seorang guru disaat menyampaikan informasi materi tentang kajian ilmu terutama kajian ilmu sains lebih khusus lahi seperti mata pelajaran fisika.
Seperti yang dijelaskan diatas, ilmu fisikan selalu dianggap sulit dipahami, membosankan, dan kurang menarik. Hal ini tentunya bukan karena fisikannya, dipastikan karena cara penyampaiannya yang berpengaruh pada kondisi lingkungan psikologis pada saat penyampaian pembelajarannya. Jika pada penyampaian pembelajarannnya hanya sebatas lambang kata dan dramatisasi, bias dipastikan keterserapan lambing-lamnga, symbol-simbl, bentukbentuk, bahkan makan-makna fisis sulit sekali terserap kedalam memori peserta didik. Oleh karena itu peran seorang guru sangatlah penting dalam memyampaikan materi yang dilengkapai dengan fasilitasi penggunaan media pembelajaran agar dapat melakukan pengamatan dan pengalaman secara langsung guna menciptakan kondisi pembelajaran secara kongkret.

Hal ini harus dipersiapkan bagi para calon-calon guru fisika agar kedepannya nanti siap diperdayakan oleh pihak sekolah yang pada dasarnya adalah pengguna lulusan dari perguruan tinggi yang bergarak dalam bidang LPTK (Lembaga Perguruan Tinggi Kependidikan).Seringkali perguruan tinggi LPTK juga minim menerapkan system pembelajaran berbasis paktikum, jika memang selalu menerapkan pembelajaran berbasis praktikum, tentunya menggunakan peralatan paraktikum yang standart. Namun, pada saat para calon guru ini lulus dari bangku perkuliahan, akan merasa kesulitan jika diterapkan secara nyata dilingkungan persekolahan yang memiliki fasilitas laboratorium yang jauh dari standart yang ada, atau bahkan tidak memiliki laboratorium. Padahal 
peserta didik di negara kita dituntut dengan acuan kurikulum yang sama. Artinya, sekolah dimanapun baik negeri maupun swasta materi yang disampaikan tetaplah sama meskipun memiliki fasilitas laboratorium yang terbatas. Mungkin bagi sekolah-sekolah unggulan peserta didiknya masih dapat menikmati fasilitas laboratorium yang memedai, sedangkan bagi sekolahsekolah pinggiran, atau sedang berkembangang belum mampu untuk memberkan fasilitas tersebut. Apalagi system pendidikan kita sudah mulai menerapkan zonasi yang pada dasarnya input SDM (Sumber Daya Manusia) baik guru maupun siswa memiliki daya saing SDM yang sama disetiap sekolah negeri maupun swasta.

Kesenjangan faslitas laboratorium merupakan masalah tersendiri bagi penerapan system zonasi, karena hal ini menjadi tidak sesuai dengan system zonasi yang tujuannya adalah pemerataan SDM namun tidak diimbangi dengan pemerataan fasilitasi sarana prasarana sekolah termasuk sarana laboratorium.Tentunya hal ini juga berpengaruh pada tingkat antusias belajar peserta didik, kondisi lingkungan belajar dan kompetisi prestasi peserta didik terhadap rancangan capaian pembelajaran.

Jika hal tersebut dibiarkan begitu saja, kelak pada masa yang akan dating akan menjadi apa putra putri penerus bangsa ini jika mengandalkan calon guru fisika yang kurang kreatif dalam menyampaikan buku teks pelajaran jika tidak terfasilitasi laboratorium.

Hal ini juga dipicu oleh rendahnya penguasaan ilmu pengetahuan dan teknologi oleh calon-calon guru fisika.Sehingga pengembanganpengembangan media pembelajaran yang membutuhkan ilmu pengetahuan dan teknologi khusus seperti pengembangan media pembelajaran yang ekonomis dan sederhana sulit dilaksanakan. Bukan karena fasilitas, tapi sebagian besar calon-calon guru fisika mengalami kesulitan untuk merancang bangun media pembelajaran sesuai standart kompetensi dasar dalam kurikulum tingkat sMP dan SMA.

Kesenjangan fasilitas ini harus diantisipasi mulai sejak dini melalui kaderisassi para calon-calon guru fisika untuk dapat menciptakan media pebelajaran yang interaktif dengan biaya yang relative murah.Sehingga pentingnya dilakukan suatu kegiatan workshop bagi para calon guru sebagai bekal agar mudah merancang bangun media pembelajaran meskipun fasilitas laboratorium disekolah tempat meraka bekerja dikatakan minim fasilitas laboratorium.

Dengan adanya pelatihan rancang bangun media pembelajaranini, maka tradisi lisan dan tulisan dalam proses pembelajaran dapat diperkaya dengan berbagai media pembelajaran. Dengan tersedianya media pembelajaran, guru pendidik dapat menciptakan berbagai situasi kelas, menentukan metode pengajaran yang akan dipakai dalam situasi yang berlainan dan menciptakan iklim yang emosionalyang sehat diantara peserta didik. Bahkan alat/media pembelajaran ini selanjutnya dapat membantu guru membawa dunia luar ke dalam kelas.Dengan demikian ide yang abstrak dan asing (remote) sifatnya 
menjadi konkrit dan mudah dimengerti oleh peserta didik. Bila alat/media pembelajaran ini dapat di fungsikan secara tepat dan proforsional, maka proses pembelajaranakan dapat berjalan efektif.Dalam pembelajaran, alat atau media pendidikan jelas diperlukan.Sebab alat/ media pembelajaran ini memiliki peranan yang besar dan berpengaruh terhadap pencapaian tujuan pendidikan yang diinginkan.

\section{METODE PELAKSANAAN}

[Times New Roman 11 bold]

Kegiatan workshop peningkatan kualitas SDM bagi calon guru fisika melalui media praktikum kompone elektronika pasif dan aktif dilakukan pada Program Studi Pendidikan Fisika Universitas Kanjuruhan Malang semester 2.Berdasarkan hasil monitoring dan wawancara dengan kelompok calon guru fisika di sekitar lokasi penerapan Iptek, maka diperoleh kesimpulan bahwa kelompok calon guru fisika di Universitas Kanjuruhan Malang masih membutuhkan dorongan, bimbingan dan pendampingan untuk meningkatkan kualitas profesiaonalisme calon guru fisika dalam menghadapi perkembangan zaman. Permasalahan yang dihadapi kelompok calon guru fisikatersebut adalah belum tersedianya penguasaan ilmu pengetahuan pengembangan media pembelajaran fisika yang ekonomis dan sesuai standart kurikulum SMA. Sehingga dalam kegiatan pengabdian ini, diadakan suatu konsep pelatihan tentang rancang bangun media pembelajaran yang sesuai dengan kompetensi dasar kurikulum di tingkat SMA. Sebelum dilakukan kegiatan workshop, telah dilakukan analisis situasi utuk mengetahui permasalahan yang dihadapi kelompok calon guru fisika dalam meningkatkan kualitas dan kuntitas profesionalisme calon guru fisika yaitu belum tersedianya suatu konsep penguasaan ilmu pengetahuan tentang rancang bangun media pembelajaran yang ekonomis dengan mengaitkan lingkungan sekitar yang terstandarisasi kurikulum SMA yang menyebabkan mekanisme pembelajaran menjadi kurang menjadi kurang menarik.Berdasarkan permasalahan tersebut, maka tim pengabdi merancang scenario kegiatan workshop tersebut selama enam jam yang terdiri sebagai berikut: $\quad 1$. Pengenalan 2. Pengkarakterisasian 3. Penerapan.

Pada kegiatan pengenalan ini telah dilakukan pengenalan tentang :

1. Pengenalan tentang pengetahuan media pembelajaran listrik dinamis.

2. Pengenalan komponenkomponen elektronika pasif dan aktif baik secara devais.

3. Pengenalan alat-alat ukur elektronika beserta penggunaannya.

Pada kegiatan pengkarakterisasian dlakukan karakterisasi mengenai :

1. Karakterisasi ciri-ciri masingmasing komponen pasif dan aktif.

2. Karakterisasi keberfungsian dari masing-masing komponen pasif dan aktif

3. Karaterisasi kelayakan melalui pengukuran secara langsung menggunakan alat ukur. 
Pada kegiatan penerapan meliputi kegiatan :

1. Penerapan komponen pasif dan aktif melalui jika digunakan pada papan rangkaian project board.

2. Penerapan penggunanan komponen pasif dan aktif pada kehidupan sehari-hari.

3. Penerapan cara penggunaan alat ukur sesuai dengan standart penggunaannya.

4. Menerapkan standart operasi dalam menjalankan sistem rancang bangun media.

5. Menerapkan hasil media yang dibuat untuk dibandingkan degan teori buku teks standart SMA sederajat baik secara teori rumus persamaan maupun serta makna fisis.

Batasan dari ketiga point kegiatan diatas berupa :

1. Media yang digunakan khusus pada sub bab materi elektronika listrik dinamis.

2. Pengunaan bahan media sebatas komponen elektronika pasif dan aktif.

3. Komponen pasif yang dgunakan terdiri dari resistor, kapasitor dan inductor.

4. Komponen aktif yang digunakan terdiri dari diode rectifier.

5. Materi diarahkan pada standart kurikulum SMA pada sub bab rangkaian listrik dinamis yang dirangkai dengan amat sederhana dan ekonomis, namun dapat membutkikan rumus matematis dan makna fisis.
Guna memudahkan proses kegiatan pengabdian ini, telah dibuat berupa alur kegiatan Pengabdian secara umum digambarkan dalam Gambar 2.
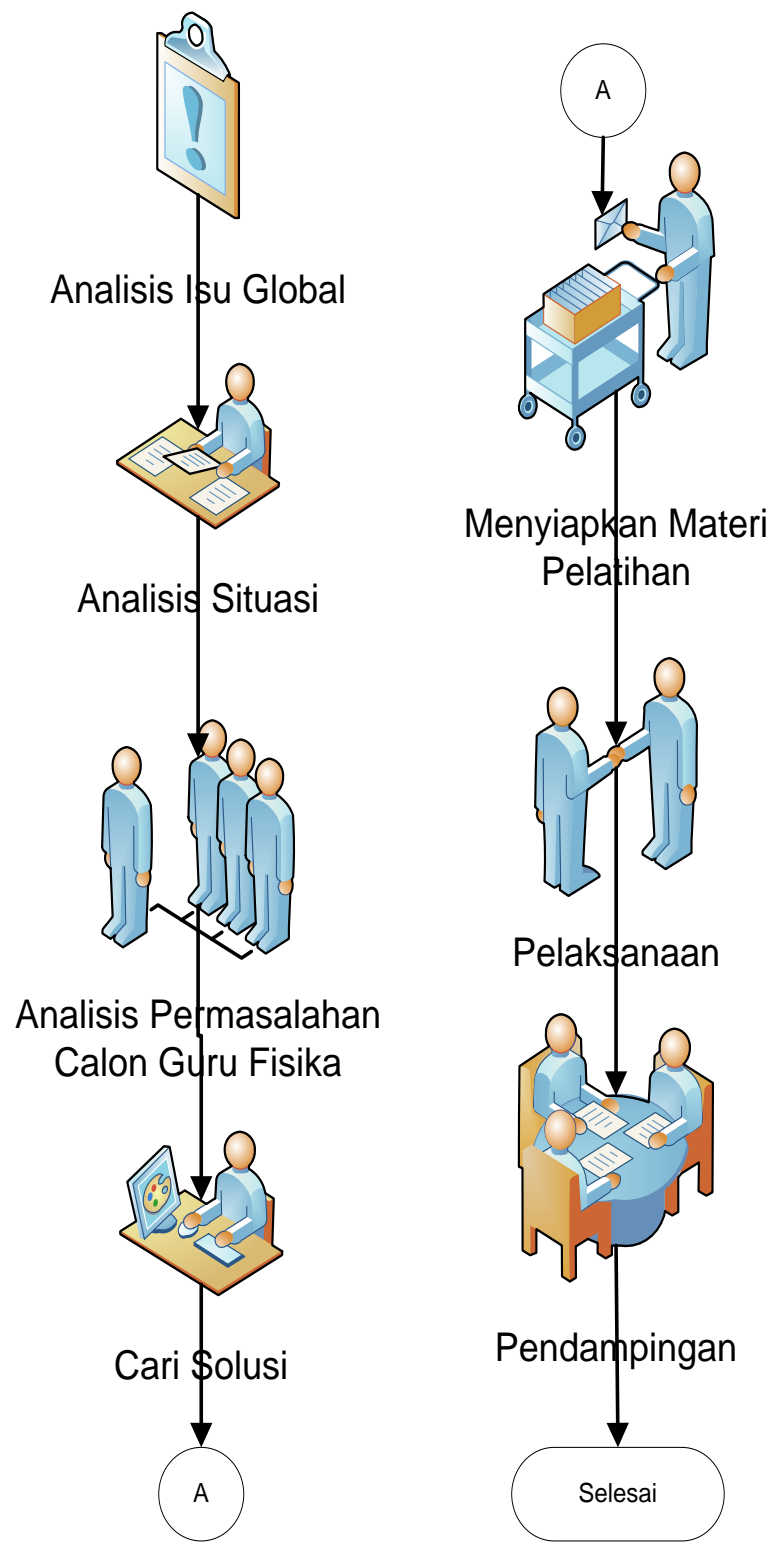

Gambar 2.Diagram alir metodepelaksanaan workshop peningkatan kualitas SDM calon guru fisika.

Gambar 2. telah ditunjukkan rencana alur kegiatan pengabdian yang dilakukan dengan melalui proses 
pelatijhan dan pendampingan. Dengan melalui pendampingan ini diharapkan calon guru fisika dapat membuat media pembelajaran yang sederhana tapi secara konsep fisika dapat dipertanggung jawabkan secara ilmiah.

Pada bagian awal kegiatan pengabdian ini, tim pengabdi melakukan anailisis situasi dengan melakukan kegiatan wawancara untuk mengetahui analisis permasalah calon guru fisika. Kegiatan wawancara ini disertai dengan kegiatan pemberian angket pengukuran kedalaman masalah bagi para calon gurufisika sewaktu masih duduk dijenjang SMP dan SMA yang terdiri dari :

1. Sewaktu saudara duduk di jenjang SMP dan SMA apakah saudara pernah membuat media pembelajaran sederhana berbasis praktikum pada sub bab listrik dinamis?

2. Sewaktu saudara duduk di jenjang SMP dan SMA apakah saudara pernah melakukan penerapan media pembelajaran berbasis praktikum pada sub bab listrik dinamis ?

3. Sewaktu saudara duduk di jenjang SMP dan SMA, apakah disekolah tempat saudara dulu ada ruang laboratorium ?

4. Seberapa seringkah saudara melakukan aktifitas laboratorium ditempat sekolah saudaradulu?

5. Sewaktu saudara duduk di jenjang SMP dan SMA, pernakah bapak/ibu guru saudara dulu memperagakan/mensimulasikan /mempraktekkan persoalanpersoalan gejala fisika didalam ruang kelas?

6. Sewaktu saudara duduk di jenjang SMP dan SMA apakah saudara pernah difasilitasi/diajak bapak/ibu guru saudara melakukan studi ekskursi untuk menggali ketrampilan sains?

7. Sewaktu duduk di jenjang SMP dan SMA apakah saudara pernah mengikuti kompetisi lomba membuat karya media pembelajaran?

Selain diberikan angket pengukuran masalah, telah dilakukan juga pengkuran pengetahuan awal (Pre-Test) dari setiap para calon guru fisika yang meliputi :

1. Apakah arti media pembelajaran menurut saudara?

2. Listrik dinamis adalah ?

3. Komponen elektronika pasif adalah?

4. Komponen elektronika aktif adalah?

5. Sebutkan jenis-jenis komponen elektronika pasif yang saudara ketahui ?

6. Sebutkan jenis-jenis komponen elektronika aktif yang saudara ketahui?

7. Sebutkan kegunaan elektronika pasif dan aktif menurut saudara ketahui?

8. Apakah saudara mengetahuli kegunaan alat ukur multimeter?

9. Menurut pengalaman saudara, jenis multimeter apakah yang saudara ketahui ? 
10. Besaran listrik apa saja yang dapat diukur pada alat multimeter ?

Pada bagian akhir dari kegiatan pengabdian ini seperti yang ditunjukkan pada Ganmbar 2 yaitu pada bagian pendampingan, dimana kegiatan tersebut adalah pendampingan selama kegiatan berlangsung maupun kegiatan sesudah worksop dilakukan. Artinya, setelah kegiatan workshop tim pengabdi tetap memberikan monitoring kepada para peserta dengan memberikan tugas tambahan kepada para calon gurufisika untuk membuat rancangan media hingga dapat diterapan.

Setelah kegiatan, tim pengabdi juga memberikan angket pertanyann untuk mengukur kedalaman pengetahuan bagi para calon guru fisika guna mengetahui perubahan pengetahuan, ketrampilan dan tingkat kepastian penyerapan materi yang sudah disampaiakn oleh tim pengabdi. Angket pertanyaan tersebut terdir dari 10 soal yang sejenis seperti pada soal sebelum kegiatan workshop dilakukan.Data angket sebelum dan sesudah kegiatan kemudian diolah menjadi dalam bentuk grafik yang represenatif guna memudahkan menganalisis ketercapaian program yang sudah dilakukakan guna memberikan informasi yang lebih reperesentatif dan memudahkan menganalisa perubaan pengetahuan, ketrampilan dan perilaku peserta kegiatan workhop.Selain itu juga dilakukan evaluasi keterlaksanaan kegiatan workshop guna mengantisipasi kekurangan yang ada disaat penerapan kegiatan yang sudah dilakukan melalui penambahan tugas-tugas setelah kegiatan bagi para calon guru fisika agar segala informasi materi yang sudah disampaikan sesuai dengan capaian target kegiatan.

\section{HASIL DAN PEMBAHASAN}

Target pencapaian di dalam ruang lingkup kegiatan workshop mutlak diperlukan untuk mengerucutkan konsentrasi dan fokus kegiatan workshop. Hal ini akan menentukan arah dan capaian hasil yang diharapkan sebagai luaran hasil workshop. Di dalam kegiatan workshop ini terdapat beberapa target utama yang ingin di capai, target tersebut di antaranya adalah:

1. Calon guru fisika mampu menggunakan alat ukur besaran listrik.

2. Calon guru fisika mampu membedakan komponen pasif dana aktif.

3. Calon guru fisika mampu mengkarakterisasi masingmasing komponen pasif dan aktif.

4. Calon guru fisika mampu merancang bangun media pembelajaran fisika penrapan sub bab listrik dinamis.

5. Calon guru fisika mampu mengoperasionalkan sistem rancang bangun media pembelajaran listrik dinamis.

6. Calon guru fisika mampu memahami dan menganalisis hasil rancangan media pembelajaran listrik dinamis.

7. Calon guru fisika mampu membuat serangkaian percobaan listrik dinamis yang sederhana, ekonomis, dan sesuai standart kurikulum SMA. 
8. Calon guru fisika yang unggul dalam bidang pengembangan media pembelajaran.

Pada kedelapan point yang sudah dijabarkan diatas, telah didapatkan hasil kegiatan workshop seprti yang ditunjukkan pada Gambar 3 .

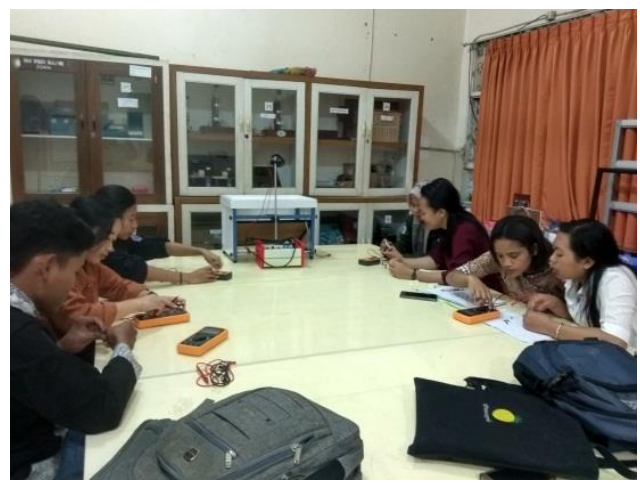

Gambar 3. Pengenalan penggunaan alat ukur

Pada Gambar 3 menunjukkan bahwa alat ukur yang digunakan untuk mengetahui besaran listrik dinamis berupa multimeter digital.Kegiatan ini di peruntukan agar peserta sebelum menggunakan alat ukur secara real harus mengetahui terlebih dahulu berupa tombol-tombol dan makna lambanglambang yang terdapat pada multimeter guna disaat dilakukan pengukuran tidak terjadi kesalahan yang kemungknann dapat merusak alat ukur tersebut.

Selain itu, di sela-sela kegiatan workshop tim pengabdi juga memberikan pertanyaan kepada peserta workshop mengenai pengetahuan, pengalaman, dan penerapan tentang penggunaan multimeter didalam kehidupan nyata. Sementara itu, tim pengabdi juga memberikan pertanyaan tentang keterkaitan lambang-lambang fisis yang ada didalam multimeter dengan materi SMP dan SMA kepada peserta sewaktu duduk dibangku persekolahan.Setelah dilakukan kegiatan pengenalan alat ukur dan pengenalan jenis-jenis komponen pasif dan aktif.Selanjutnya dilakukan pengkarakterisasian masing-masing komponen pasif dan aktif seperti yang ditunjukkan pada Gambar 4.

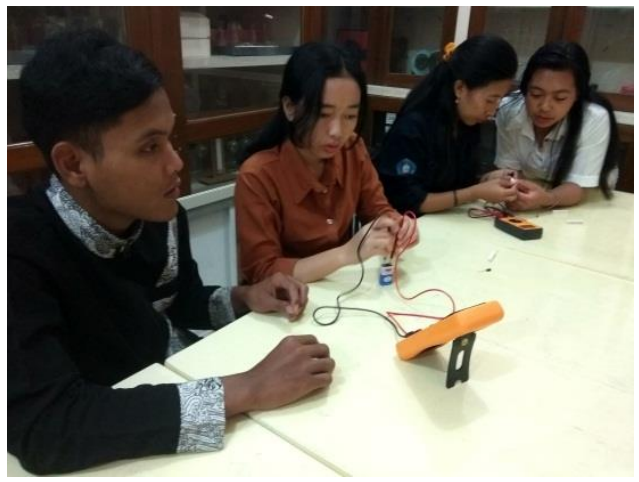

Gambar 4.Karakterisasi komponen pasif, aktif dan komponen pendukung kegiatan workshop.

Gambar 4 meunjukkan bahawa kegiatan pengkarakterisasian masingmasing komponen pasif, aktif dan komponen pendukung seperti baterai yang diseri dan parallel menggunaka alat ukur multimeter.Hal ini dilakukan agar peserta workshop mengetahui secara real kegunaan multimeter jika dilakukan pengukuran masing-masing komponen untuk mengetahui besaranbasaran fisis yang digunakan.

Sebagai contoh, bagaimana multimeter difunmgsikan untuk mengukur besaran tegangan, resistasi, kapasitansi, dan induktansi.Pada masing-masing besaran tentunya tombola tau rotary multimeter juga dikondikan dan disesuaikan dengan 
lambing-lambang besaran yang akan diukur agar hasil pembacaan pada multimeter sesuai dengan besaran yang diukur. Hal ini diperuntukan agar peserta kegiatan dapat mengetahui secara real dan memahami dari segi makna fisis besaran dan satuan elektris jika diaplikasikan pada pengkaraktersiasian masing-masing komponen.

Selain itu, penggunaan multimeter juga tidak diperbolehkan mengukur secara sembarangan.Terdapat rentang batasan-batasan yang diijinkan dalam penggunaannya. Seperti jika diperlakukan pengukuran besasran elektris resistansi 1 mega ohm, maka tidak diijinkan memutra rotary multimeter pada rentang 0-100 ohm. Hal ini mengakibatkan multimeter tidak dapat mendeteksi nilai besaran tersebut yang diindikasikan display pembacaan pada multimeter tidak muncul nilai angka. Hal-hal seperti ini harus segera diantisipasi, karena jika dilakukan pada pengukuran-pengukuran selain besaran resistansi sperti besaran tegangan DC/AC bahkan aruas DC/AC akan berakibat fatal yang dapat mengakibatkan kerusakan pada multimeter karena kesalahan penggunaan rentang pengukuran. Sehingga pada kegiatan pengkarakterisasian ini seringkali tim pengabdi melakukan demonstrasi diawal untuk mengantisipasi kesalahan dari peserta akibat pengguaan rotary rentang pengukuran yang berdampak pada kerusakan pada alat ukur yang digunakan dan keselamatan kerja dari peserta workshop. Oleh sebab itu, tim pengabdi selalu melakukan pendampingan kepada masing-masing peserta workshop agar sesuai dengan instruksi dari pemateri untuk memastikan keselamatan kerja.

Pada kegiatan penerapan, telah dilakukan penerapan masing-masing komponen pasif dan aktif agar dapat dirangkai untuk dapat dilakukan rancang bangun media listrik dinamis seperti yang ditunjukkan pada Gambar 5.

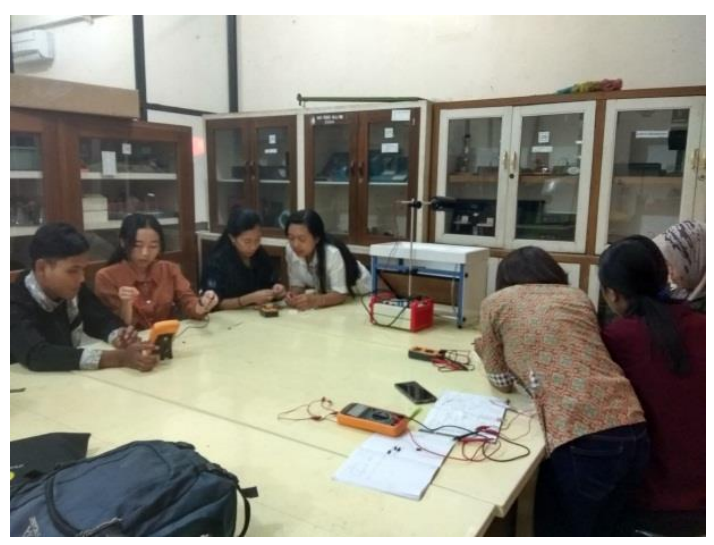

Gambar 5. Penerapan komponen pasif dan aktif

Pada Gambar 5 telah dilakukan penerapan komponen pasif dan aktif menggunakan media papan rangkaian project board guna menghasilkan set up praktikum listrik dinamis. Perangkaian komponen pasif yang masing-masing terdiri dari resistor, kapasitor, dan inductor telah diuji coba pada masingmasing komponen.Seperti contoh merangkai hubungan seri resistor, merangkai hubungan seri kapasitor, dan merangkai hubungan seri inductor, merangkai hubungan parallel resistor, merangkai hubungan parallel kapasitor, merangkai hubungan parale inductor.

Setiap rangkaian baik rangkaian secara seri maupun parallel kemudian diukur menggunakan multimeter untuk 
mencari hambatan pengganti resistor, kapaistor dan inductor dalam kondisi rangkaian terbuka. Kemudiada rangkaian dirangkai secara tertutup menggunakan sumber tegangan baterai juga diterapkan pertanyaan yang samayaitu untuk mencari hambatan pengganti resistor, kapasitor, dan inductor. Meskipun terlihat sama mencari hambatan pengganti, namun kondisi rangkaian berbeda, sehingga penggunaan persamaan juga berbeda tapi hasil yang didapat sama. Hal ini dilakukan untuk melatih para peserta workshop guna meningkatkan kinerja berpikir ilmiah. Hasil penerapan tersebut kemudian dikaitkan dengan teori yang terdapat didalam kurikulum SMP dan SMA pada sub bab listrik dinamis agar para peserta workshop yang mayoritas adalah para calon guru fisika dapat membandingkan hubungan secara teori, penerapannya, dan makna fisis berdasarkan acuan media yang sudah diterapkan.

Selanjutnya dilakukan penerapan rangkaian komponen aktif yang terdiri dari diode rectifier.Rangkaian komponen aktif tersebut telah dirangkai dengan menggunakan sumber tegangan DC untuk mencari perilaku kondisi bias maju dan bias mundur. Sebagai contoh satu diode rectifier dan dihubungkan seri dengan satu buah resistor dan ampere meter yang dihubungkan dengan sumber tegangan baterai, kemudian polaritas positif baterai dihubungkan dengan pada kutub anode diode selanjutnya polaritas negative baterai dihubungkan dengan kutub katode diode.Selanjutnya diamati pada bagian display ampere meter yang menunjukkan besarnya nilai arus listrik. Jika menunjukkan nilai besarnya arus litrik, maka dapat dipastikan diode tersebut mengalami bias maju.

Namun pada kondisi sebaliknya untuk membuktikan perilaku bias mundur.Satu diode rectifier dan dihubungkan seri dengan satu buah resistor dan ampere meter yang dihubungkan dengan sumber tegangan baterai, kemudian polaritas positif baterai dihubungkan dengan pada kutub katode diode selanjutnya polaritas negative baterai dihubungkan dengan kutub anode diode.Selanjutnya diamati pada bagian display ampere meter yang menunjukkan tidak ada nilai arus listrik. Jika menunjukkan nilai besarnya arus litrik sama dengan nol, maka dapat dipastikan diode tersebut mengalami bias mundur. Hasil penerapan tersebut kemudian dikaitkan dengan teori yang terdapat didalam buku Fisika Modern Seri Bahan Persiapan Olimpiade Fisika pada sub bab konduktifitas listrik zat padat. Hal ini dilakukan agar para calon guru fisika dapat dipersiapkan untuk membimbing dan membina siswa persiapan olimpiade fisika pada tempat sekolah mereka bekerja, karena pada dasarnya setiap sekolah dimanapun pasti memiliki keinginan untuk memajukan SDM melalui berbbagai kompetisikompotisi ilmiah seperti kegiatan olimpiade.

Hasil dari kegiatan yang sudah dilakukan elah dilakukan pengukuran pengetahuan melalui instrument sesuai dengan soal yang terdapat pada bab metodologi pelaksanaan yang sudah dipaparkan diatas yang berjumlah sepuluh soal dengan jumalah tujuh responden. Hasil pengukuran pengetahuan Pre-Test dan Post-Test 
telah dipaparkan dalam bentukt ditunjukkan pada Gambar 6.

representative garafik seperti yang

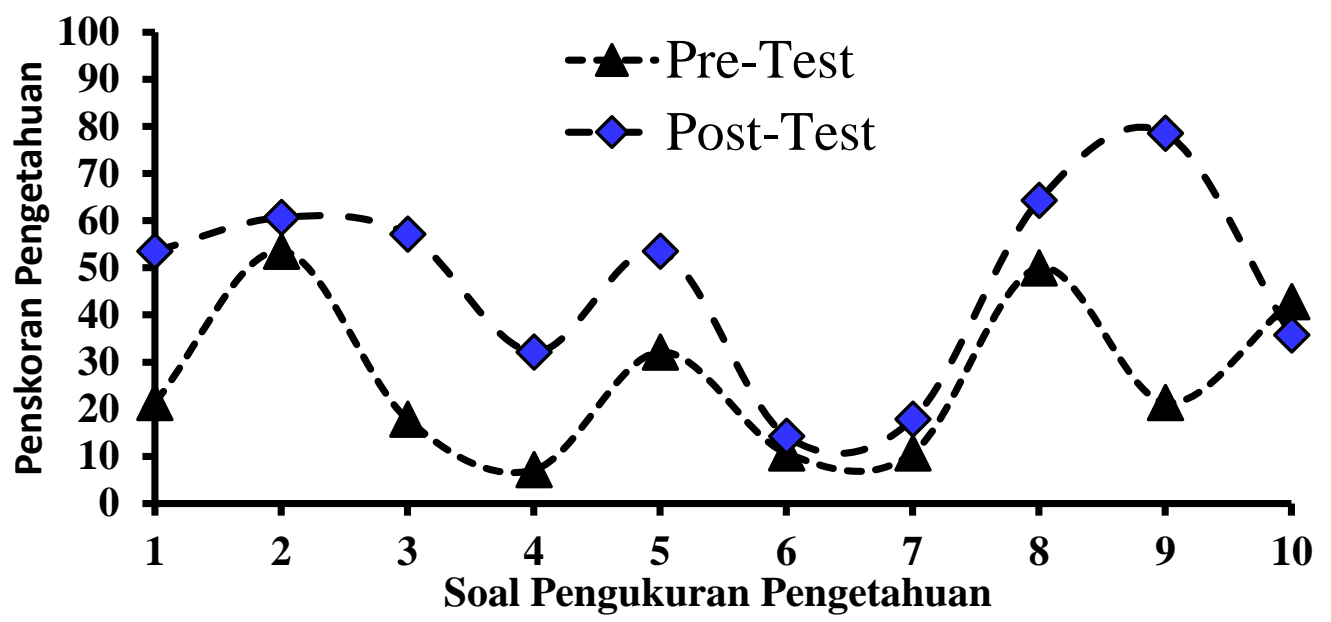

Gambar 6.Representatif data hasil pengukuran pengetahuan sebelum dan sesudah kegiatan workshop.

Gambar 6 merupakan data reperentatif hasil tes pengukuran pengetahuan awal sebelum kegiatan dilakukan dan setelah kegiatan workshop menunjukkan para peserta yaitu para calon guru fisika menunjukkan perubahan pengetahuan dan perilaku ketrampilan kerja ilmiah yang signifikana.

Pada bagian soal No 9 yaitu tentang penggunaan alat ukur berupa jenis multimeter yang saudara ketahui sebagian besar para peserta workshop dapa menjawab dengan tepat, karena multimeter yang digunakan pada kegiatan workshop telah menggunakan semua variasi jenis multimeter yaitu jenis multimeter analog dan digital.Artinya, metode pelaksanaan kegiatan dengan menggunakan pola pembelajaran pengalaman langsung yang ditunjukkan pada Gambar 1 sangat efektif untuk merekam memori para peserta calon guru fisika.

Berdasarkan hasil tes pengukuran penetahuan awal yang terdiri dari sepuluh soal tersebut telah didapatkan rerta nilia tes pengukuran awal sebesar 26.78 sedangkan rerata tes pengukuran pengetahuan setelah kegiatan didadpatkan rerata sebesar 46.78.Sehingga rerata selisih peningkatan pengetahuan dari para peserta workshop sebesar 20. Meskipun tidak meningkat secara drastis, setidaknya para peserta workshop memiliki pengalaman dan bekal secara nyata untk bias dikembangkan kedalam tahap pengembangan media pembelajaran yang lebih kompleks.

\section{SIMPULAN}

Kegiatan workshop peningkatan SDM bagi calon guru fisika melalui media praktikum komponen elektronika 
pasif dan aktif menunjukkan pola perubahan perilaku yang nyata pada tingkat ketrampilan kerja ilmiah pada menggunakan alat ukur untuk mengukur besaran listrik sesuai dengan standar prosedur penggunaannya. Selain itu para peserta juga mampu membedakan dan mengkarakterisasi masing-masing komponen aktif dan pasif serta dapat merancang dan mengaplikasikan kedalam bnetuk media pembelajaan yang sederahana, ekonomis, guna memperoleh pembuktian-pembuktian teori fisika yang sesuai dengan standart kurikulum SMP dan SMA.

Berdasarkan hasil pengukuran tes kemapuan pengetahuan awal dan hasil pengukuran tes pengetahuan setelah kegiatan, telah didapatkan rerata tes pengetahuan awal sebesar 26.78 sedangkan rerata tes pengetahuan akhir setala kegiatan sebesar 46.78 dengan selisih rerata peningkatan sebesar 20 . Berdasarkan hasil observasi selama kegiatan, para peserta menunjukkan sikap motivasi belajar yang antusias dengan adanya proses didkusi dan tanya jawab disaat proses kegiatan workshop berlangsung. Peningkatan pengetahuan rerata sebesar 20 ini dilampau masih dapat ditingkatkan lagi, sehingga disarankan untuk ditambahkan alat peraga simulasi berbantuan aplikasi perangkat lunak guna menambah pengetahuan dan pengalaman belajar bagi para peserta calon guru fisika seperti bantuan software proteus.

\section{DAFTAR RUJUKAN}

Aden Arif Gaffar, 2019. "Pembelajaran Berbasis Praktikum Virtual Untuk Meningkatkan Sikap Ilmiah Siswa Kelas X Pada Materi Invertebrata".Jurnal Bio
Educatio, Volume 1, Nomor 1, Oktober 2016, hlm. 18-25

Sukartini \& Faisal. 2009. Teori Psikologi Pendidikan. Dalam Ali, M., Ibrahim, R., Sukmadinata, N.S. Sudjana, D., dan Rasyidin, W (Penyunting).Ilmu dan Aplikasi Pendidikan. IMTINA. Bandung.

Erniwati, Rosliana Eso, Sitti Rahmia. 2014. "Penggunaan Media Praktikum Berbasis Video Dalam Pembelajaran IPA Fisika Untuk Meningkatkan Hasil Belajar Siswa Pada Materi Poko Suhu dan Perubahannya "Jurnal Sains dan Pendidikan Fisika Jilid 10, Nomor 3, Desember 2014, hal $269-273$.

Chairuddin, 2019. "E-Learning (Edublogs) Social Media Based: Its Implementation In Teaching Learning At Islamic Senior High School Bangkalan. STKIP PGRI Bangkalan".Jurnal Pengabdian Masyarakat Khatulistiwa, Vol 2 No 2. Hal 46-50.

Duda, H. J., 2010, "Pembelajaran Berbasis Praktikum dan Asesmennya pada Sistem Ekskresi untuk Meningkatkan Kemampuan Berpikir Kritis Siswa Kelas XI", VOX Edukasi, Vol 1, No 2, Hal: 29-39.

Rustaman, N., Dirdjosoemarto, S., Yudianto, S. A., Achmad, Y., Subekti, R., Rochiantaniawati, D., dan Nurjhani, M., 2005, Strategi Belajar Mengajar Biologi, Malang: UM PRESS.

Alhikmahsby.com "Mas Guru", Seputar Hasil Belajar Siswa, 28 Agustus 2012, <https://ayip7miftah.wordpress.co 
m/2012/08/28/seputar-hasil-

belajar-siswa/> [Diakses Pada 6

Januari 2019]. 